\title{
Hydrocarbon Prospect of Nigeria's Gongola Basin Based on Gravity Data Interpretation
}

\author{
Nsikak E. Bassey ${ }^{1}$. Jonathan Barka ${ }^{2}$. Hayatudeen Musa ${ }^{3}$. Abubakar Takana ${ }^{4}$ \\ ${ }^{I}$ (Geology Dept, Akwa Ibom State University, Mkpat Enin, PMB 1076 Uyo, Nigeria) \\ ${ }^{2}$ (Geology Dept, Gombe State University, PMB 127 Gombe, Nigeria) \\ ${ }^{3}$ (Geology Dept, Modibbo Adama University of Technology, PMB 2076 Yola, Nigeria.). \\ ${ }^{4}$ (Survey And Geoinformatics Dept, Modibbo Adama University Of Technology, PMB 2076 Yola, Nigeria)
}

\begin{abstract}
With an upbeat in petroleum exploration efforts in Nigeria's inland Basins emphasis has been on basinal structure. In this study attempt is made to analyze processed gravity maps of the western sector of the Gongola Basin for qualitative interpretation and depth computations. The study area lies between latitude $9^{\circ} 57^{\prime}$ $-10^{\circ} 24^{\prime} N$ and longitude $10^{\circ} 23^{\prime}-10^{\circ} 50^{\prime} \mathrm{E}$. The geology of the area is dominantly Tertiary sediments of the Kerri Kerri Formation overlying Cretaceous sediments, Precambrian gneisses occur marginally to the west. Gravity data were processed using Winglink ${ }^{\circledR}$ (version 2.03.01). Residual data were filtered to generate $1^{\text {st }}$ horizontal and $1^{\text {st }}$ vertical derivatives maps, and upward continued maps. Oasis Montaj software (7.0.1) was used to generate radial spectral graphs for depth computation. Surfer 11 surface mapping software was used for data contouring. The derivative maps show zones of high gradient attributed to basement related faults. Upward continued map indicate anomalies with $N W, N-S$ and ENE trends interpreted as expressions of deep structures of the Basin. Gravity residual profile across the study area presents a horst - graben basement structure. Radial spectral analysis curves yield two segments - D1 and D2 with depths in excess of $4 \mathrm{~km}$, and 0.5-1.5 km respectively. The DI depths are considered sub-basins which probably have necessary physical condition of temperature and pressure for hydrocarbon generation/accumulation.
\end{abstract}

Keywords: Gravity data, data processing, radial spectral analysis, basement structure, hydrocarbon prospect

\section{Introduction}

The study area lies in North East Nigeria between longitudes: $10^{\circ} 23^{\prime}$ to $10^{\circ} 50^{\prime} \mathrm{E}$, and latitudes: $9^{\circ} 57^{\prime}$ to $10^{\circ} 24^{\prime} \mathrm{N}$ (Fig. 1). It is within the western sector of the Gongola Rift Basin, a N-S arm of the larger NE trending Benue Trough. The Benue Trough is a plate tectonics reminiscence of the separation of the South American continent from Africa/formation of the equatorial Atlantic. The area is majorly drained by the Gongola River. The elevation ranges from $300-550 \mathrm{~m}$ above sea level (Lagos datum). The major towns are Alkeleri, Akko, Dukku, Ganjuwa and Darazo.

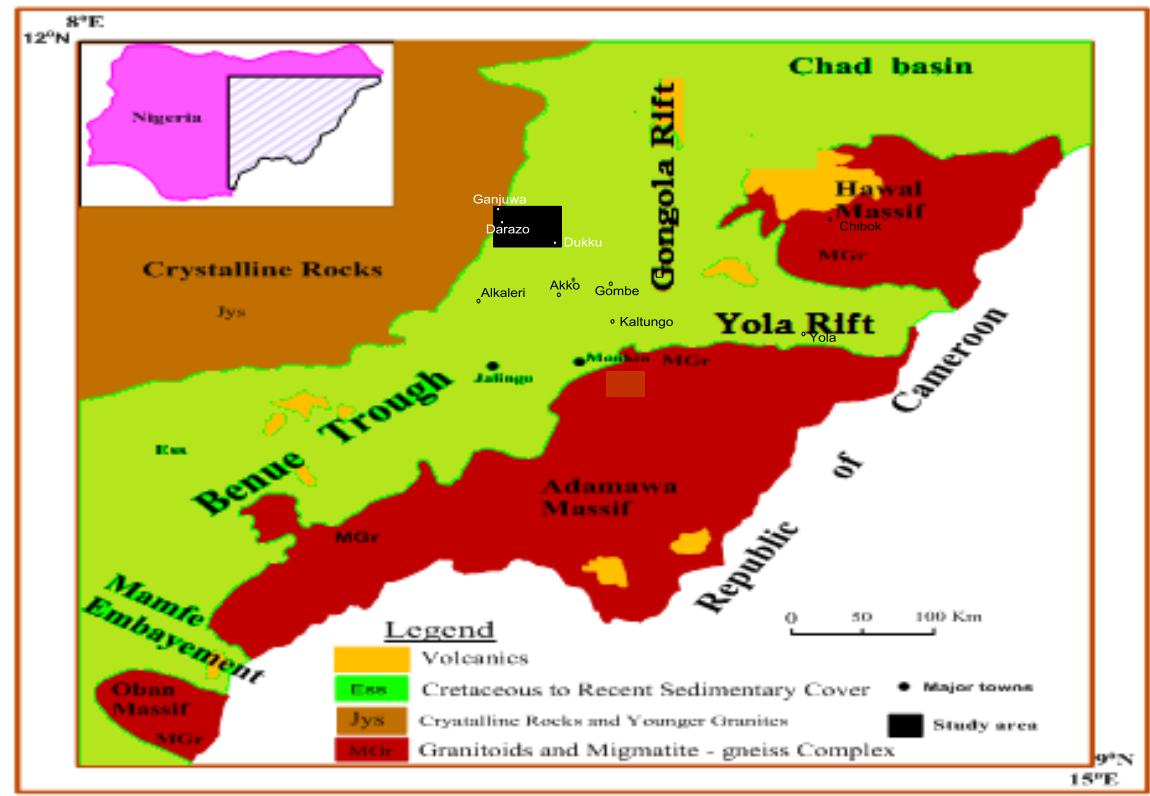

Fig. 1: Location map of study area within the geologic setting of the Benue Trough. (Adapted and modified from [1]). 
Geologically the area has Cretaceous and Tertiary sedimentary rocks dominantly, with Precambrian Basement gneisses being minor. The latter is found at the western margin of the study area. The Cretaceous rocks consist of shales, sandstones, siltstones and limestone which may be up to 5-6 km thick. These are capped by rocks of the Tertiary Kerri-Kerri Formation. These rocks form the Kerri-Kerri Formation (an iron rich sandstone formation) consisting of a horizontal series of beds lying unconformably on the Cretaceous sediments. The Kerri- Kerri rocks do not exceed $300 \mathrm{~m}$ in thickness [2][3]. Whereas the Cretaceous rocks may be up to 5-6 km in thickness. The superficial sand cover is red brown colour because of limonite content derived from the ferruginous sandstone. Occasionally thin layers of marl are found.

\subsection{Previous studies}

Gravity studies in the Benue Trough have received considerable attention and almost the entire length of the Trough has been covered [4][5][6][7][8]. These workers have independently interpreted the data in terms of an uplifted mantle and the thinning of the crust beneath the Trough. These authors have also presented depth estimates of sediments to vary from 1.5 to about $7.0 \mathrm{~km}$. These sediments decrease in thickness towards the northern part of the Trough where they attain local values of $2 \mathrm{~km}$ or less [9] [10] indicative of isolated basins.

[11] gave a detailed analysis of the regional gravity field over the Trough. Their 2-D models of the Bouguer anomaly over different sections of the Trough confirm a crustal thickness with a range of 22-32 km. Different amounts of crustal extension has been estimated for the Trough. Values vary from 95, 65 and $55 \mathrm{~km}$ for the Middle Benue, Gongola and Yola rifts respectively [8]. [12] presented results of gravity profile data across the Mamfe Embayment-a SE and coastal arm of the Benue Trough (Fig.1). The authors posit that the Basin floor is characterized by short wavelength gravity low produced by low density Cretaceous sediments with a maximum thickness of $3 \mathrm{~km}$. In an undated report [13] however obtained values of 130, 118 and $78 \mathrm{~km}$ for the middle, Gongola and Yola Rifts respectively. [14] used aerial photographic and aeromagnetic data in their study of Guyuk area (part of the Gongola Basin). They presented a two-depth source model based on spectral analysis. A depth of $1.9 \mathrm{~km}$ was assigned to the basement while a shallower depth range of 0.512 to $0.670 \mathrm{~km}$ was attributed to near surface intrusive and low lying river valleys.

[15] had reported the existence of petroleum in the study area. [16] in his doctoral thesis attempted to quantify the petroleum deposit using 2D Fourier analysis and Gauss theorem in the study area. While [17] in his doctoral thesis on utilized residual gravity to determine the existence of mineral resource in the area and proposed drilling points for it. Both authors in joint work [18] gave the density of the mineral resource as 0.85 $\mathrm{gm} / \mathrm{cm}^{3}$ and suggest it is petroleum.

[19] working on aeromagnetic maps on the Gongola Basin and using spectral analysis gave depth of averages of $1.2 \mathrm{~km}, 4.03 \mathrm{~km}$ and $5.39 \mathrm{~km}$ for $1^{\text {st }}, 2^{\text {nd }}$ and $3^{\text {rd }}$ magnetic level in the area. [20] used second vertical derivative gravity data (as input data) to compute depths in the Gongola Basin and they arrived at depths of $5.2 \mathrm{~km}$ for the SE part and $7.0 \mathrm{~km}$ for the NE part. [21] used multivariate statistical analysis of residual gravity anomalies to analyse the Gongola Basin for hydrocarbon. [22] used the downward continuation approach integrated with density log. From their computations they found that the upper and lower depth limits of anomalous mass are at 2015 and $2017 \mathrm{~m}$ respectively. They also reported that from the density contrast between these limits is gaseous hydrocarbon. Using polynomial fitting on aeromagnetic data [23] places a sedimentary thickness of about $5 \mathrm{~km}$ around Gombe and Akko etc.

\section{Methodology and Workflow}

The data for present work were acquired by Compagnie Generale De Geophysique, Nig. Ltd in 1995, for Shell Nigeria Exploration and Production Company (SNEPCO), as part of the exploration work of the latter for petroleum in the Gongola Basin, North east Nigeria. The study area is OPL 803/806/809 in the Gongola Basin. It has 1831 observed gravity stations with an interval of $500 \mathrm{~m}$.

In the present work attempt is made to interpret processed gravity data of the study area. The work flow chart is shown in Fig. 2. It also presents depth (sediment thickness) computations based on radially averaged power spectrum. The following filtering techniques were applied on the residual data:

a) Horizontal derivative or horizontal gradient: In this technique faults and other abrupt geologic discontinuities (edges) are detected based on high horizontal gradient on potential field. The $1^{\text {st }}$ horizontal gradient is used.

b) Vertical gradient: In this technique the vertical rate of change of the potential field is estimated. It is a high pass filter. The $1^{\text {st }}$ vertical gradient is used here. Both techniques may enhance noise in some cases.

c) Upward continuation: This is a low pass filter applied to potential field data to simulate the result of a survey conducted as if the data were at a higher elevation. This filter enhances broad regional features and separates long wave length anomalies from short wavelength anomalies. The filtering processes were done using Winglink (version 2.03.01). 
Radially averaged spectral analysis was also done using Oasis Montage (7.0.1) on the bouguer anomaly data to compute depths to basements beneath the sedimentary basin.

The digital data were imported to the oasis montaj to generate bouguer anomaly map and the residual gravity map. The residual data were divided in to 20 blocks of equal size and of dimensions, 4 minutes of longitude and 5 minutes of latitude respectively. Each block was windowed in order to perform the analysis using magmap module of the oasis montaj. The blocks were numbered from left to right (Fig. 3.). An attempt is also made to compare/interprete elevation (topographic) profile with corresponding residual gravity profile.
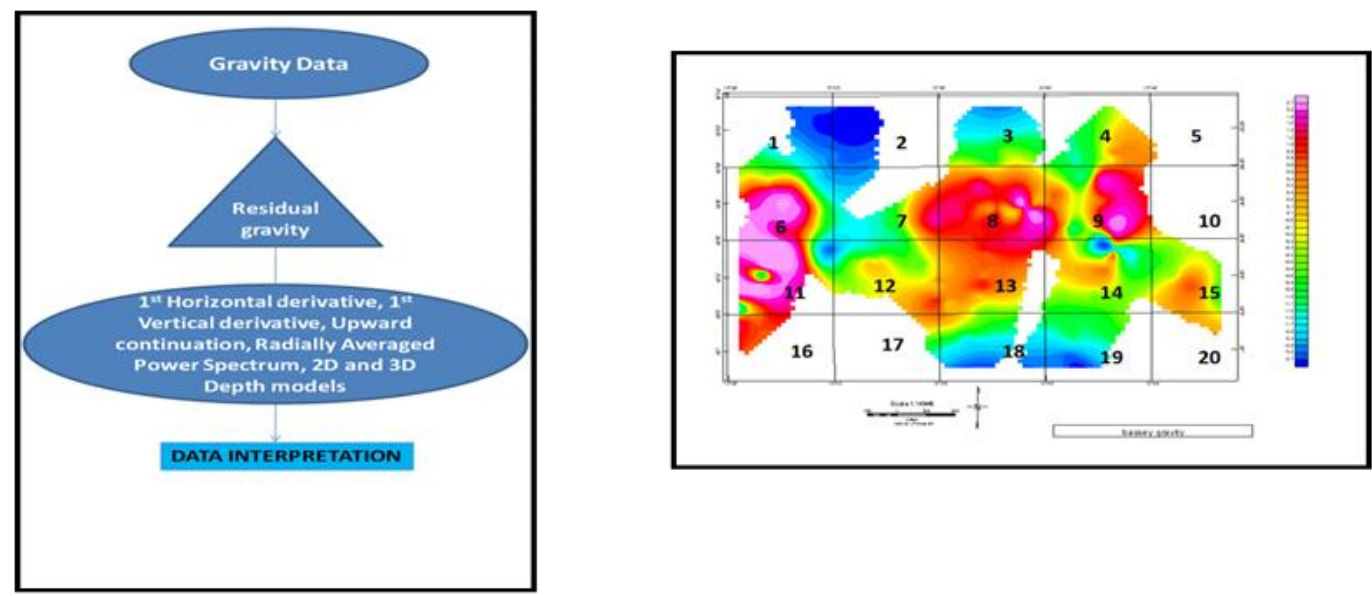

Fig. 2: Work flow chart.

Fig. 3: Residual gravity map with survey area divide into 20 blocks for spectral analysis using oasis montaj. Note areas without data coverage.

\section{Results and Discussion}

I) Residual Gravity Map: (Fig.4). The anomalies show low (-45 mgals) and high (4.5 mgals). The west central margin shows the high region while the low region of -4.5 to $1 \mathrm{mgal}$ is found to the east of it. Another prominent gravity low area is found eastward with a range of -4.5 to about -0.5 mgal. The low regions are interpreted in terms of low density sediments. Much of the study area has intermediate gravity values $(-0.5$ to $2.5 \mathrm{mgal}$ ) attributed to the presence of Kerri - Kerri Formation which is an alternations of ferruginous sandstones, shales and siltstones [3]. The gravity high anomalous zone towards the west margin is attributed to the crystalline basement rock (gneisses) that outcrop there.

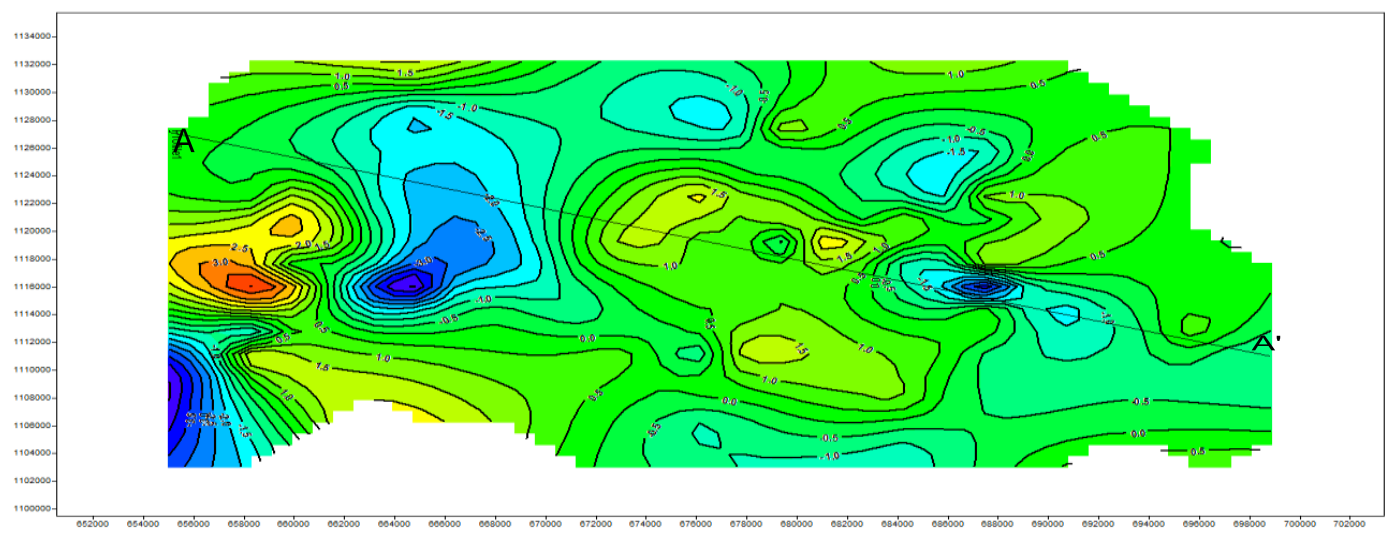

Fig.4: Residual gravity map - data has been extrapolated into areas initially without coverage and contoured by the software (Winglink).

II) $1^{\text {st }}$ Horizontal Gradient map: (Fig.5). This map has strong anomalous areas westward with gradient of 0.0015 to $0.0020 \mathrm{mgal} / \mathrm{km}$, similar feature is found eastward. These are interpreted as basement related faults.

III) $1^{\text {st }}$ vertical Gradient maps: (Fig.6). This shows some similarity in the distribution of the anomalous zones with the horizontal gradient map, except for a stronger E-W disposition of the anomalies in the vertical gradient map. Similar explanation to the horizontal gradient anomalies is given for the vertical gradient map since they show essentially the similar features. Also the central zone of anomalies coincides with the zone of underground mineral (petroleum?) accumulation according to [16]. 


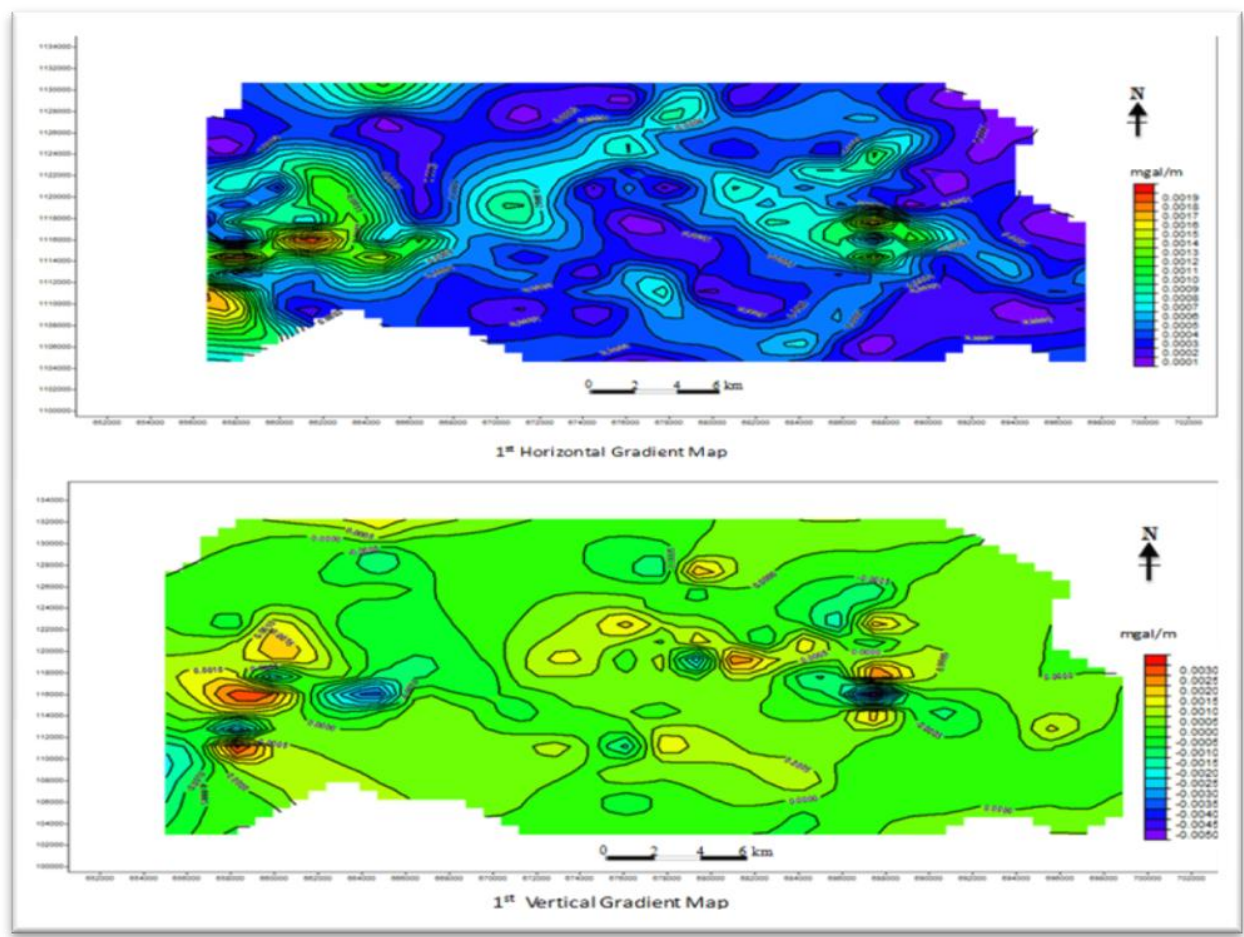

Fig. 5 (Top): $1^{\text {st }}$ horizontal gradient map and Fig. 6 (bottom): $1^{\text {st }}$ vertical gradient map.

IV) Upward Continuation map: (Fig.7). This show regional nature of the anomalies with trends: NW, N-S, and $\mathrm{NE}$ (A,B,C respectively). These trends are attributed to deep regional structures related to the formation of the Benue Rift. A and $\mathbf{C}$ form a conjugate lineament pair. [24] [25] reported such conjugate within the Yola Rift. According to these authors they manifest on rock outcrops as joints and faults. The NE lineament could be genetically related to the sinistral NE trending Kaltungo fault in the Gongola Basin [26]. The N-S lineament B coincides with trend of the Gongola Rift [27] [28]. [29] mapped shear zones, faults, and joints in the granitic basement rocks of Chibok area NE Nigeria. He said these manifest as structural trends in the $\mathrm{NW}, \mathrm{NE}$ and $\mathrm{N}-\mathrm{S}$ directions which gives credence to the present interpretation. The NW, NE and N-S gravity lineaments are signatures of deep seated basement structures.

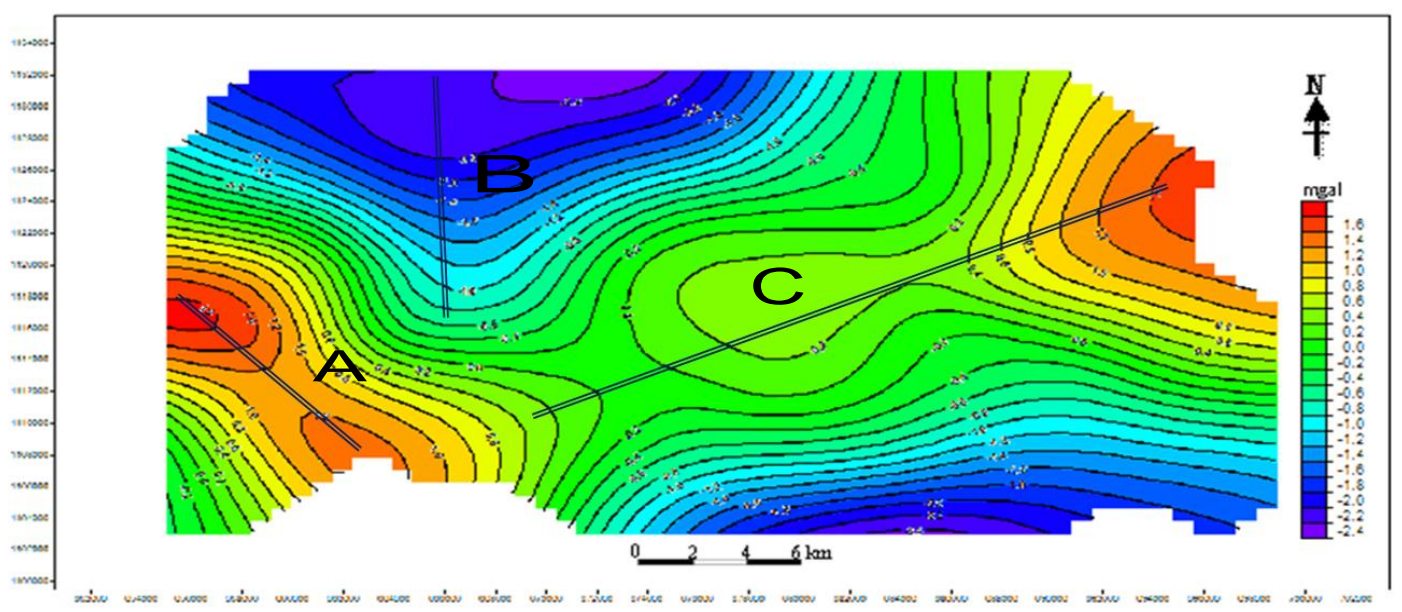

Fig. 7: Upward continued gravity map (continuation to $1 \mathrm{~km}$ ).

V) Elevation map: (Fig.8a). This map shows high zones to the NW (400-410 m) and to the SW (400-430 m). We have a low intervening region between the two with elevation $270-380 \mathrm{~m}$.) The central part coincides with the Gongola river valley (Fig.1). An elevation profile A-A' and the corresponding gravity (residual) profile is presented in (Fig.8b). From the gravity profile the gravity field is fairly uniform except from 2500 
$\mathrm{m}$ to $3500 \mathrm{~m}$ where we have a major gravity high ( $<25 \mathrm{mgal}$ ) flanked by two gravity minima of about -30 mgal. These gravity high zones bounded by low zones depict a horst - graben structure beneath the Gongola basin. The horst -graben structure seems to reflect on sediment tectonics also as reported by [29].

VI) Radially Average Spectral Depths: (Fig. 9). The computed depths range from 2 to $6 \mathrm{~km}\left(\mathrm{D}_{1}\right)$ and from 0.5 to $1.5 \mathrm{~km}\left(\mathrm{D}_{2}\right)$. Since the gravity data acquired did not cover every area, with data extrapolation by the computing software depths of 8,10,7 km were computed in blocks 2, 5 and 10, (Fig. 3 ) respectively. Block 17 also has sparse gravity data and on extrapolation depth of $4.5 \mathrm{~km}$ was computed. These depths may only be confirmed by drilling. Fig. 10 shows computed depth (D1) contour map of the study area.

Two depth profiles are drawn from it E-W, and N-S. The profiles were carefully drawn to ensure they cross areas of gravity data coverage. These are through blocks $6,7,8,9$, for profile 1 and through blocks $3,8,13$ and 18 for profile 2. (Fig.10).

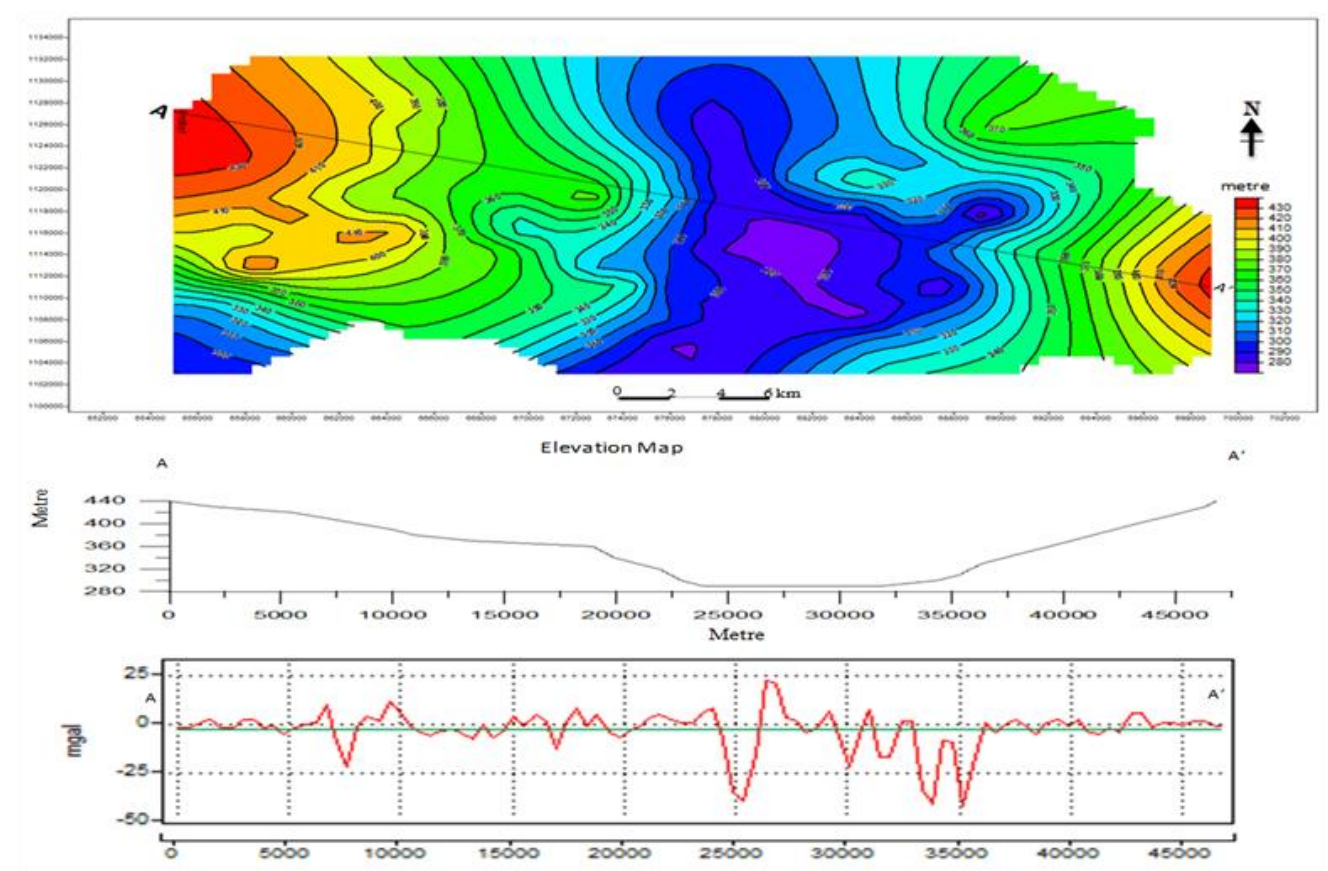

Fig. 8a (top): Elevation map and 8b (bottom): elevation profile A-A' and corresponding gravity profile.

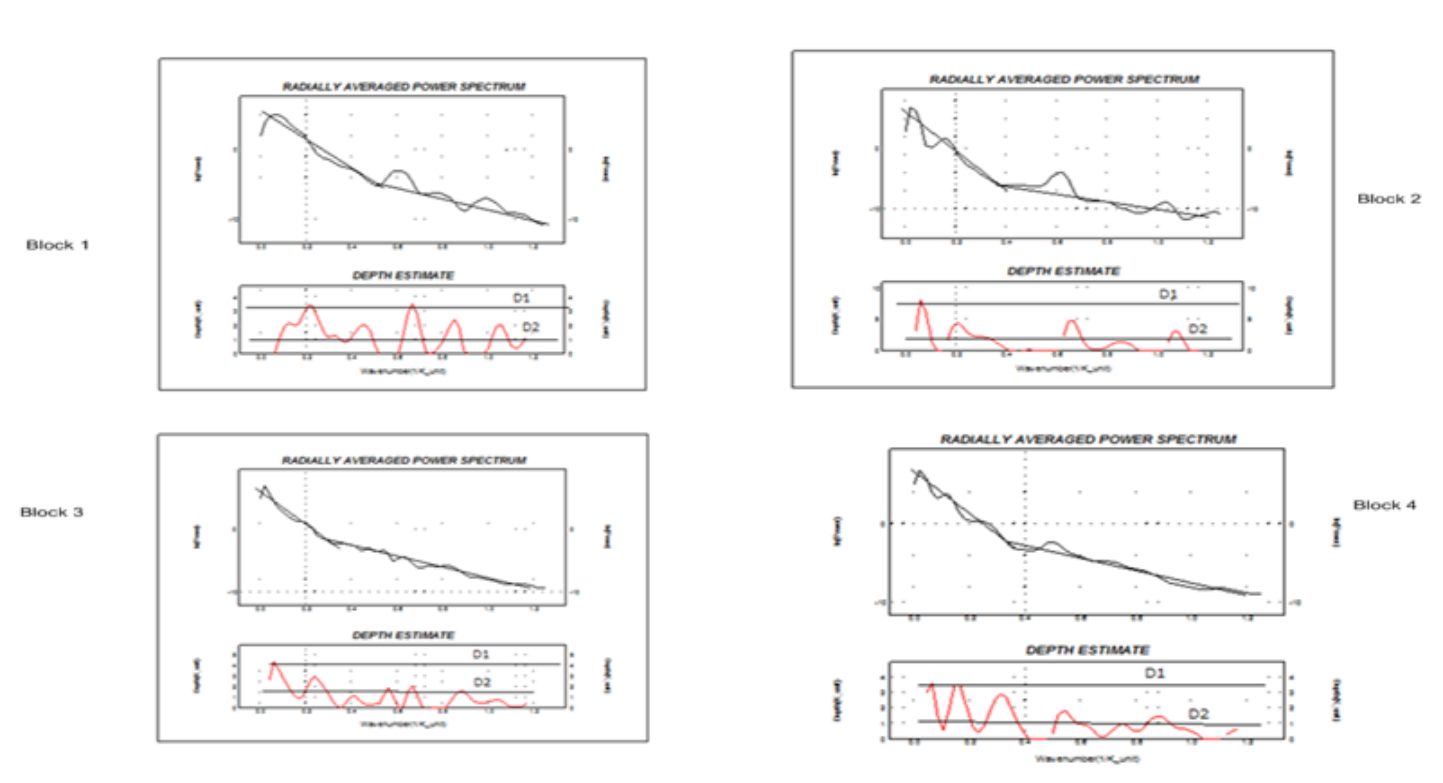

Fig. 9: Radially averaged spectral graphs for blocks 1-4 


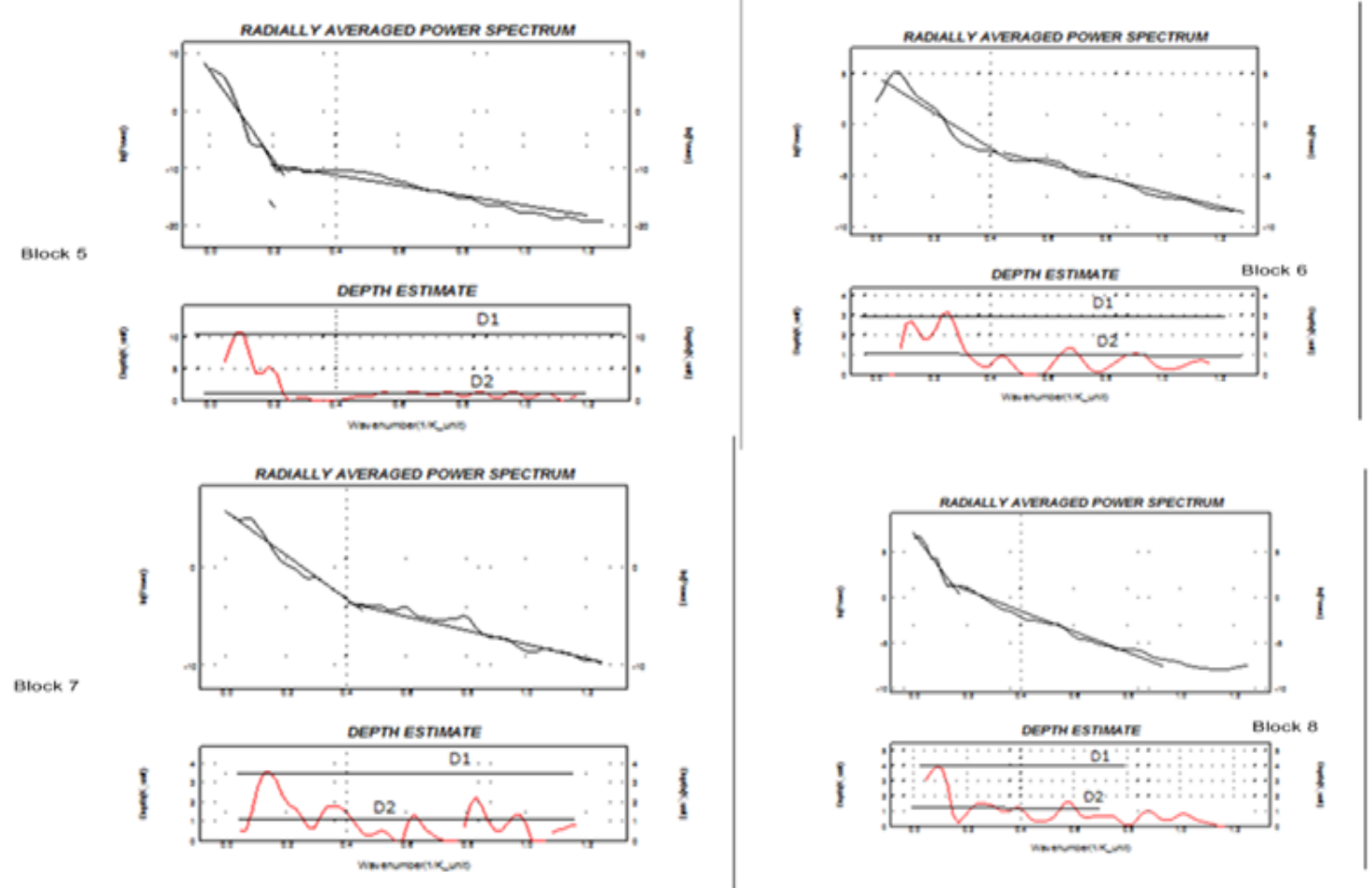

Fig. 9 continued: spectral curves for blocks 5-8.
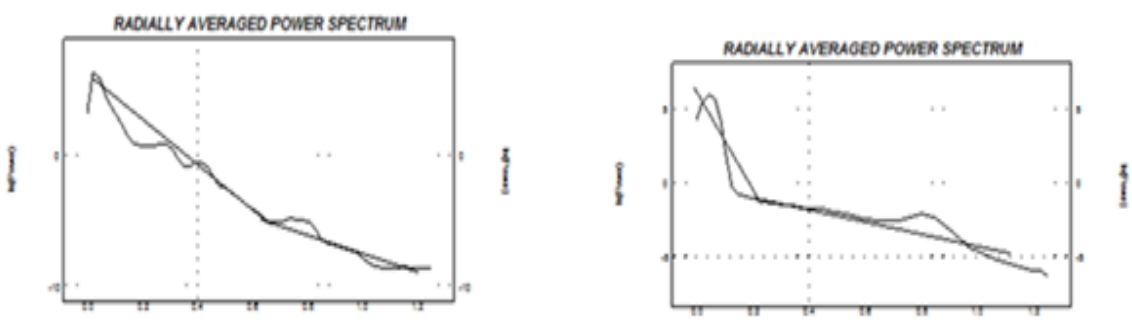

Block 9
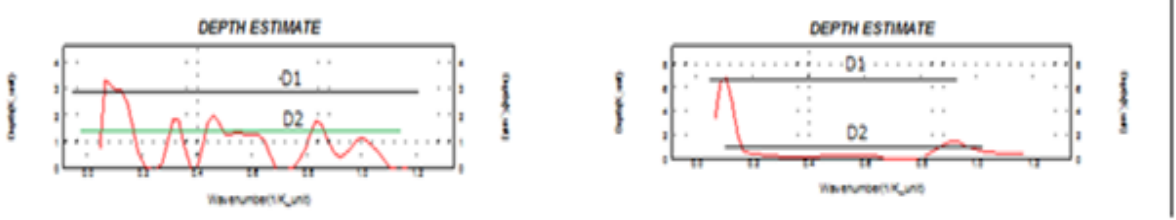

Block 10
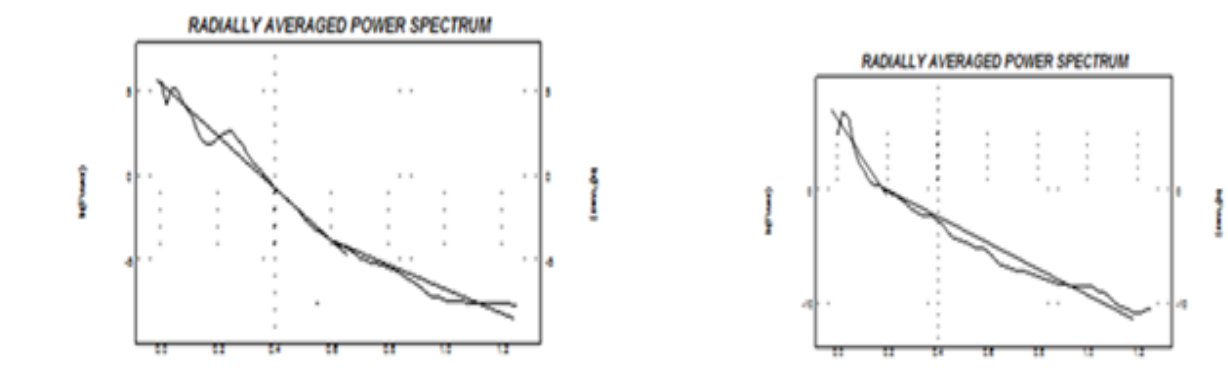

Block 11
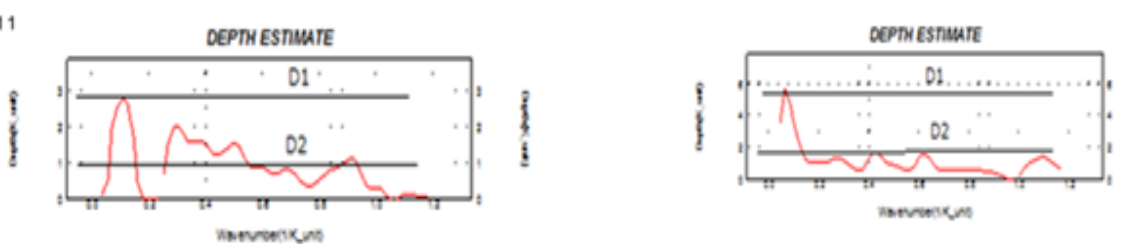

Block 12

Fig. 9 continued: spectral curves for blocks 9-12. 

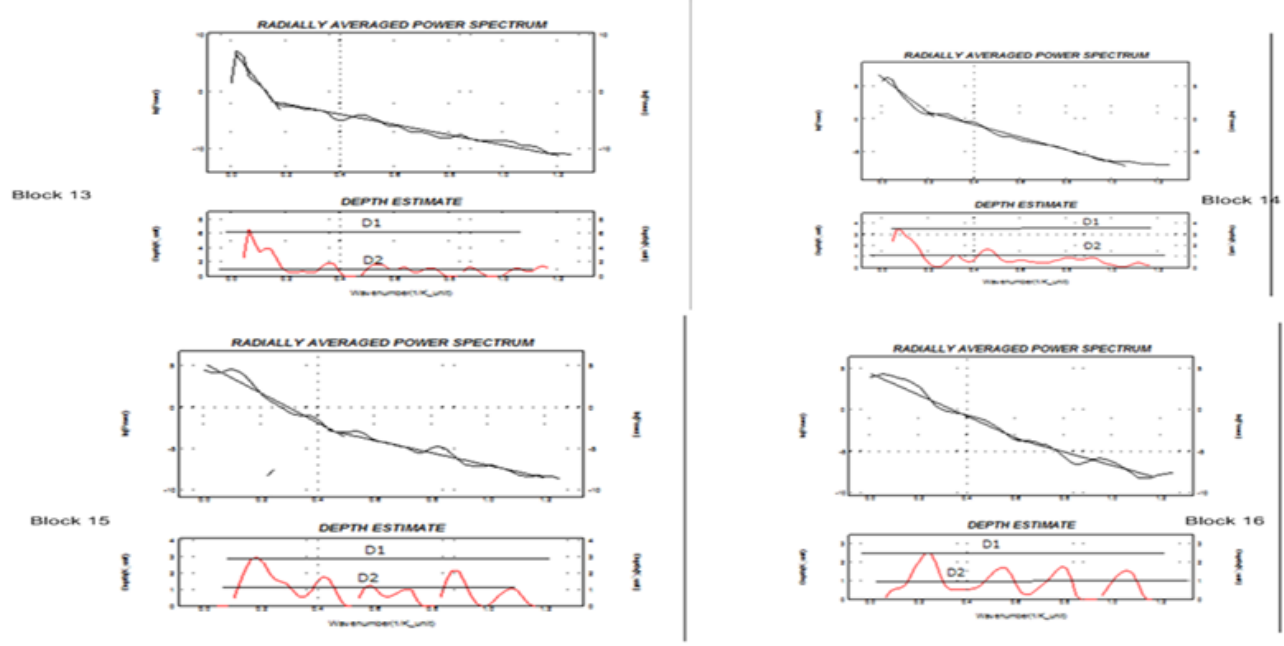

Fig. 9 continued: spectral curves for blocks 13-16.
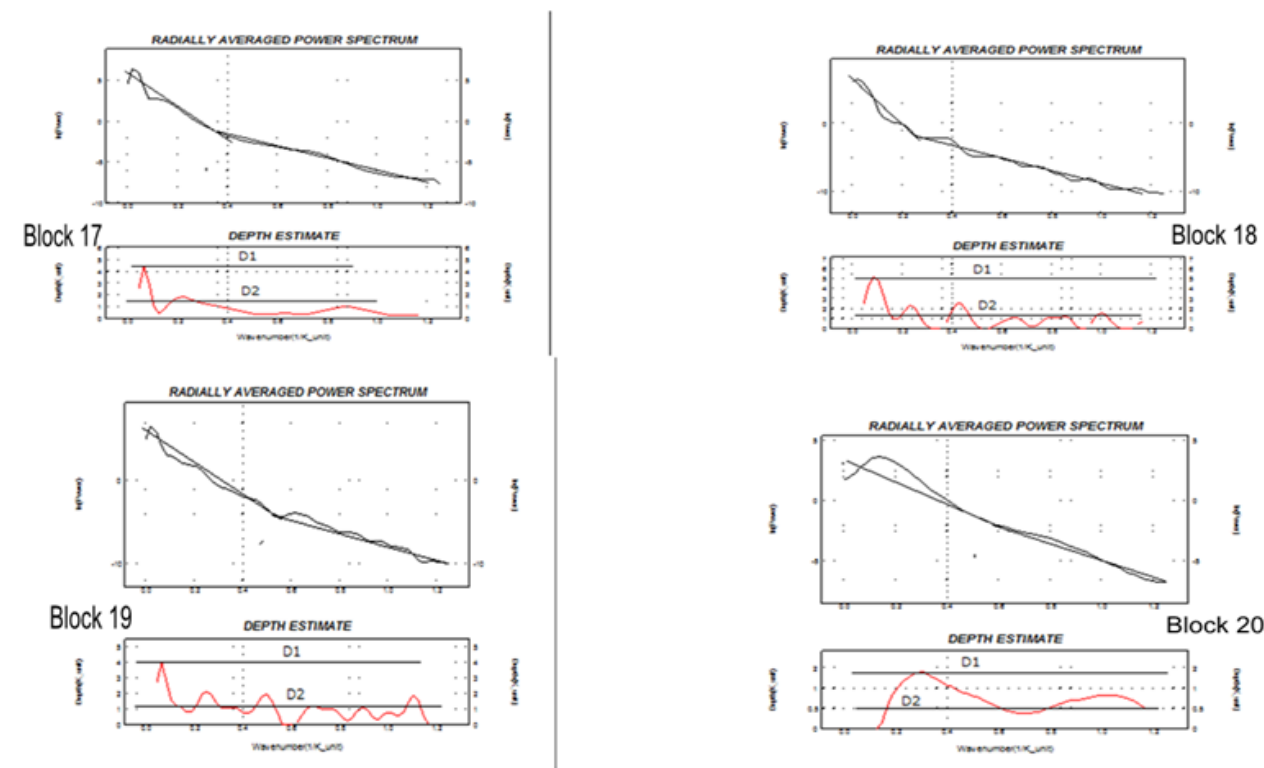

Fig. 9 continued: spectral curves for blocks 17-20.
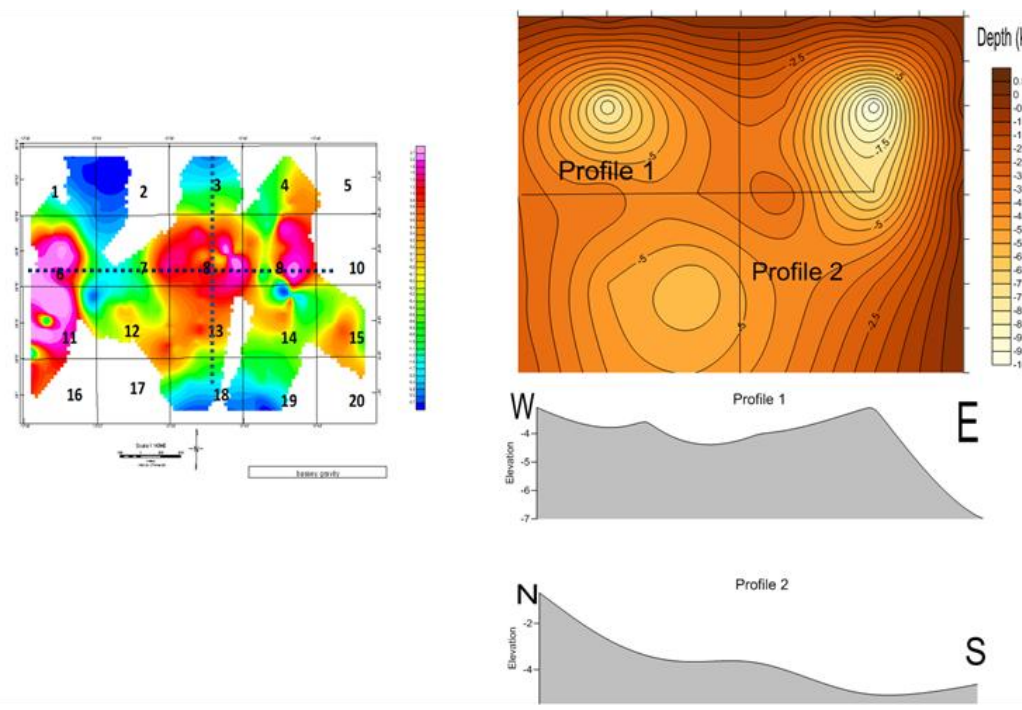

Fig. 10: Depth contour map from radially averaged power spectra with two profiles shown below. Profiles were drawn so that they pass through areas of gravity data coverage as indicated on residual map to left. 
The depth profiles are presented as negative elevation (in $\mathrm{km}$ ). On the E-W depth profile the deepest portion occurs centrally at about $4.5 \mathrm{~km}$ while on the N-S profile the depth of the basin increases southwards to $>4 \mathrm{~km} .3$-D depth maps are shown in Fig. 11. The depths for the various blocks are presented in Table 1 and the average depth was compared with what was obtained by other authors as shown in $\mathrm{T}$ able 2 . It is important to note that block 8 has a depth of $4 \mathrm{~km}$ and lies in the area where [16] predicts petroleum occurrence. The computed depths (except for the high values) are in consonance with those presented by [31] from gravity datasee [30] Fig.70 and Fig. 115. Also [32] reported that in the Gongola basin a series of N-S trending faults appear to dominate the region, subdividing it in to parallel to sub parallel N-S and fault bound basins. Also [33] who worked on the Lower Bebue Trough ( Mamfe Embayment and environs) recognized grabens ,half grabens and deep sedimentation (depocentres) and interpreted them as hydrocarbon related structures. By implication recognition and mapping of the horsts-grabens in the Benue Rift is crucial in any hydrocarbon prospecting venture.

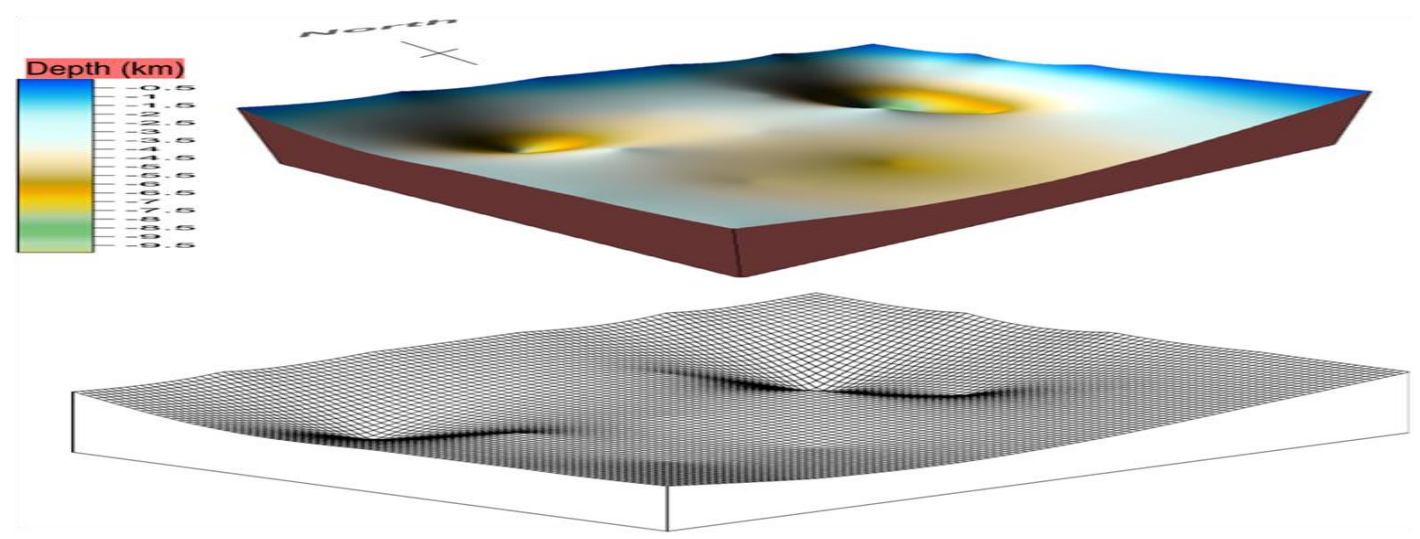

Fig. 11: 3-D colour map of depth to basement in study area, below is isometric projection of the map.

Table 1: Spectral Results of Depths in km for D1 and D2.

\begin{tabular}{|c|c|c|c|c|c|c|c|c|}
\hline Block & D1(km) & D2 (km) & Block & D1(km) & D2 (km) & Block & D1(km) & D2 (km) \\
\hline 1 & 3 & 1 & 8 & 4 & 1.5 & 15 & 3 & 1 \\
\hline 2 & 8 & 2 & 9 & 3 & 1.5 & 16 & 2.5 & 1 \\
\hline 3 & 4 & 1.5 & 10 & 7 & 1 & 17 & 4.5 & 1.5 \\
\hline 4 & 3.5 & 1 & 11 & 2.8 & 1 & 18 & 5 & 1.5 \\
\hline 5 & 10 & 1 & 12 & 5 & 2 & 19 & 4 & 1 \\
\hline 6 & 3 & 1 & 13 & 6 & 1 & 20 & 2 & 0.5 \\
\hline 7 & 3.5 & 1 & 14 & 2.5 & 1 & & & \\
\hline
\end{tabular}

Table 2. Estimated Depths To Basement By Various Authors.

\begin{tabular}{|l|l|c|c|}
\hline S/N & Authors & Depth to basement & Hydrocarbon Type \\
\hline 1 & Benkhelil et al.(1986) & $6 \mathrm{~km}$ & \\
\hline 2 & Abubakar et al. (2010) & $5.39 \mathrm{~km}$ (average & \\
\hline 3 & Epuh et al. (2011) & $5.2 \mathrm{~km}$ (SE part), $7.0 \mathrm{~km}$ (NE part) & - \\
\hline 4 & Salako (2014) & $5 \mathrm{~km}$ & Unspecified Petroleum \\
\hline 5 & Takana \& Idowu (2014) & - & Gas \\
\hline 6 & Epuh et al. (2014) & $2.015-2.017 \mathrm{~km}$ & \\
\hline 7 & Present work & $>4 \mathrm{~km}$ & \\
\hline
\end{tabular}

The $\mathrm{D}_{2}$ depths are shallow depth and with a range of 0.5 to $1.5 \mathrm{~km}$ are rather shallow for petroleum generation. They may be reflective of near surface basement rocks. Hence prospecting efforts should be in $\mathrm{D}_{1}$ depth range where sub basins are likely to be and sediment thickness high enough to provide the needed temperature and pressure for hydrocarbon generation with presence of source rocks.

\section{Conclusion}

The work presents an analytical approach to gravity data of the west sector Gongola rift. Using modern potential field processing techniques, areas of high derivative anomalies have been observed and interpreted in terms of fault zones. Regional gravity trends of NW, NE and N-S have been recognized and attributed to deep crustal structure which manifest on outcrops as joint and faults. The gravity data reveals a horst -graben basement configuration with depth to basement computations in excess of $4 \mathrm{~km}$. The presence of sub basins is consistent with reports from previous workers. The work presents the basinal structure in captivating 3D graphics and brings together depth estimates by various workers. Petroleum prospects appear likely in depth 
zones $>4 \mathrm{~km}$, these areas may have the needed physical conditions of temperature and pressure required for hydrocarbon generation. Recognition and mapping of sub Basins/depocentres is crucial in hydrocarbon prospecting ventures in the Benue Rift.

\section{Acknowledgement}

The authors acknowledged with deep indebtedness Shell Nigeria Exploration and Production Company (SNEPCO) for making the gravity data available for research and to authors whose works were consulted.

\section{References}

[1]. I.V. Haruna, D.M. Orazulike, A.B. Ofulume, Some petrological and mineralogical constraints on the source and processes for uranium mineralization on the granitoids of Zing-Monking areas, Adamawa massif. Global Jour Geol. Vol 9 (2), $2011,23-134$.

[2]. J.D, Falconer. 1911. The geology and geography of Northern Nigeria. (McMillian, London 1911) 295p.

[3]. J.D.Carter, W. Barber. E.A.Tait \& J.P. Jones, The geology of parts of Adamawa, Bauchi and Bornu provinces in Northeastern Nigeria. Bull. Geol. Surv. Nigeira, (30). 1963, 1-109.

[4]. C.R.Cratchley, and J.P. Jones, An interpretation of the geology and gravity anomalies of the Benue valley, Nigeria. Overseas geol. Surv. Geophy. Paper (1). 1965. 1-26.

[5]. V.A. Artsybashev and C.A. Kogbe,. Crustal structure of the Benue Valley Area (Nigeria) Geol. Rdsch. (64), 1974, 324-329.

[6]. C. Adighije,. Gravity field of Benue Trough Nigeria - Nature Phy. Sci. 282, 1979, 199-201.

[7]. D,E, Ajakaye and C.O.Ajayi, The origin and peculiarities of the Nigerian Benue Trough: Another look from recent gravity data obtained from the Middle Benue. Tectonophysics 80, 1981,285 - 303.

[8]. J.D. Fairhead and C.S.Okereke, A Regional gravity study of West Africa Rift System in Nigeria and Cameroon and its tectonic implication. Tectonophysics 143: 1987, 141-159.

[9]. B.J.O. Okafor \& C.O.Ofoegbu, Gravity and magnetic study of part of Northeastern Nigeria. Records of Geol. Surv. Nigeria 1988, 10 .

[10]. I.B. Osazua, D.E. Ajakaiye, \& P.J.T.Verheijen, Analysis of the structure of part of the upper Benue Rift valley on the basis of new geophysical data. Earth Evol. Sci., 2. 1981, 126-135.

[11]. Elf Nigeria Ltd., Structural interpretation of the Benue Trough and Bornu Basin: Geological Interpretation of Radar Imagery, Gravity and Aeromagnetic data and field data. (Internal Report, Lagos, 1985) 59 P.

[12]. C.S. Okereke and C. Onwuemesi, Gravity anomalies in the Nigerian sector of the Mamfe Basin. Jour. Of Mining and Geology vol 25 (1\&2). 1989, $211-214$.

[13]. K.M. Onuoha and C.O. Ofoegbu, Subsidence and evolution of Nigeria's continental margin: Implications of data from Afowo - 1 well. Marine and Petroleum Geology 5. 1988, 175-181.

[14]. N.E. Bassey, A. Nur and G.I. Obiefuna , Analyses of aerial photographic and aeromagnetic data over Guyuk area N.E. Nigeria. Jour. Of Mining and Geol. Vol. 36 (2).2000, 145-152.

[15]. SNEPCO, Gongola Basin, Nigeria - Blocks 803, 806, 803, Final Report on Gravity survey. (Submitted to Shell Nigeria Exploration and production Co. Nigeria 1995).

[16]. A. Takana, Gravimetric Technique for determination of quantity and type of underground mineral Resources in Gongola Basin, Nigeria. (Unpublished PhD thesis, Survey and Geoinformatics Dept, Modibbo Adama Univ. of Technology, Yola, Nigeria 2014).

[17]. T.O. Idowu, 2005. Determination and utilization of optimum residual gravity anomalies for minerals exploration. (Unpublished PhD Thesis University of Lagos 2005).

[18]. A. Takana and T.O. Idowu, Determination of type of underground mineral deposit in Gongola Basin Nigeria, using gravimetric Technique. International Jour of Sc. \& Tech. vo.1 4(1). 2014, 17 - 25.

[19]. Y.I. Abubakar, M,N. Umegu, and S.B Ojo, Evolution of Gongola Basin, Upper Benue Trough N E Nigeria. Asian Jour of Earth Sciences 3, 2010,:62-72.

[20]. E.E. Epuh, P.C. Nwilo, D.O.Olorode, and C.U. Ezeigbo, Basement depth estimation of the Gongola Basin using second vertical derivative data as input anomaly profile. European Jour. Of Scientific Research. Vol. 61, issue 1.2011, 172.

[21]. E.E. Epuh, P.E. Nwilo, D.O. Olorode, andC.U. Ezeigbo, Multivariate statistical analysis of Gongola Basin Residual Gravity anomalies for hydrocarbon exploration. Jour of Computations \& Modeling vol. 2 (1). International Sc. Press 2012, 53 - 76

[22]. E.E.Epuh, P.E. Nwilo, D.O. Olorode and C.U. Ezeigbo, Downward continuation of Gongola Basin Residual Gravity Anomalies using Density Log. Jour of Computations \& Modeling Vol. 2(International Sc. Press 1), 2014.1-22.

[23]. K.A. Salako, Depth to Basement determination using source parameter imaging of aeromagnetic data: an application to upper Benue Trough and Bornu Basin N. E. Nigeria. Academic Research Jour. Vol. 5(3).2014, 74-86.

[24]. N.E. Bassey, E.F.C. Dike, and O.K. Likkason, Digital filtering of Aeromagnetic maps for lineament detection in Hawal Basement Complex of Hawal Area, N.E. Nigeria. Jour. Min. Geology, 48 (1). 2012,1-11.

[25]. N.E. Bassey, Statistical study of alignments of volcanic and sub-volcanic basic rocks in Hawal Basement complex, North East Nigeria. US Open Environ. \& Earth Sc. Jour. Vol. 1 (1) .2013, 01-13.

[26]. J. Benkhelil, Structural map Of Upper Benue valley. Jour. Min. Geol. 1., 1982,140 - 151. 29. N.E. Bassey, A Tectonic Interpretation of a linear magnetic anomaly over Chibok N. E. Nigeria. Global Jour. Geological Sc. 4(1), 2006,73-78.

[27]. J.C, Maurin J. Benkhelil \& B. Robineu, Wrench tectonics in Upper Benue, N.E. Nigeria: Influence on geodynamics of the Cretaceous Benue Trough. $13^{\text {th }}$ Colloquium of African Geol. ST Andrews 1986, 199.

[28]. M. Guiraud, Geological map of part of upper Benue valley- Explanatory Note. (Elf Nigeria Ltd 1989)16p.

[29]. N.E. Bassey, A Tectonic Interpretation of a linear magnetic anomaly over Chibok N. E. Nigeria. Global Jour. Geological Sc. 4(1). 2006, 73-78.

[30]. M.B. Abubakar, A.S. Maigari, S.Y.D. Babangida. A. Wan Hasiah, I.H. Ahmed, S.J.John, U.A. Bappah,. and H.A Abdulkarim, A refocus on the tecto-stratgraphic evolution of the Upper Benue Trough N E Nigeria: Implications on petroleum exploration. Bull. Nigerian Assoc. Petroleum Explorationist vol.26 (1), 2014, 27-33.

[31]. J. Benkhelil, Structure and geodynamics evolution of intracontinental Benue Trough (Nigeria). PhD thesis University of Nice, France (Elf Nigeria Ltd publication 1986).

[32]. M.E. Offodile, Appraising geology, structure and Environments of deposition as indicators of mineral occurrences in the Gongola Basin of the Upper Benue Trough of Nigeria. In: In celebration of 70 in anniversary and 42 years of active professional practice in geology and related sciences - Occasional papers vol. 1. No. 1, (Publ. by Meccon Geol. and Engineering Services, Ltd. Jos, Nigeria 2006). 
[33]. A.A. Okiwelu, E.E.Okwueze, P.O. Akpan, \& I.A.Ude, Basin framework and basin restructuring of Lower Benue Trough, West Africa based on regional magnetic field data: tectonic and hydrocarbon implications. Earth Sc. Research, vol.4,No1. Publ. Canadian Centre for Earth Science and Education. 2015, 1-20. 